\title{
Temeljna načela i postupci u pretvaranju sirove dijalektološke građe u znanstveni rječnik
}

\author{
ĐURO BLAŽEKA \\ Učiteljski fakultet Sveučilišta u Zagrebu - Odsjek u Čakovcu, \\ Ante Starčevića 55, HR-40000 Čakovec,djuro.blazeka@vus-ck.hr
}

\section{SCN III/1 [2010], 54-73}

Avtor predstavlja svoje izkušnje pri pisanju znanstvenega narečnega slovarja, ki je nastajal na osnovi surovega gradiva ljubiteljskih zbiralcev besedja. Sprva navaja pomanjkljivosti tovrstnega gradiva in postopke prevpraševanja, popravljanja in odstranjevanja, zatem razpravlja o postopkih širjenja zbranega gradiva ter vse skupaj ponazarja s primeri iz Rječnika govora Svetog Đurđa (Rječnik ludbreške Podravine), ki ga je sestavil skupaj s Stjepanom Belovićem, učiteljem in ljubiteljem svojega rodnega kajkavskega govora. Zaključuje, da lahko prvovrsten znanstveni slovar nastane le v sodelovanju med nestrokovnjakom in strokovnjakom, pri čemer prvi nikakor nima samo stranske vloge.

The author describes his experience in writing a scientific dialectological vocabulary starting from the raw materials collected by nonprofessionals. First he gives "bad" examples of materials of that kind as well as of procedures of reconsideration, correction and elimination. Then he discusses procedures for expansion of the collected material. All this is illustrated by examples from The Dictionary of Sveti Đurd (The Dictionary of the Ludbreg Podravina region) that the author compiled together with Stjepan Belović, a local teacher and a devotee of the local Kajkavian dialect. He concludes that a first-rate scientific dictionary can be only written through collaboration between amateurs in the field and the professional expert, where the non-professional amateur by no means plays a minor role in the collaboration.

Ključne besede: kajkavsko narečje, govor Svetega Đurđa, narečna leksikografija, zbiranje in obdelava gradiva, koncept slovarske iztočnice

Key words: kajkavian dialect, subdialect of Sveti Đurđ, dialectological leksikography, collecting and treatment materials for a dialect dictionary, concept of dictionary entry 


\section{Uvod}

U literaturi se obično spominju dva načina prikupljanja leksika za dijalektalne rječnike (»dirigirano terensko istraživanje na temelju upitnika« i »slobodno istraživanje leksika« $\left.{ }^{1}\right)$. No kako su danas dijalektolozi zbog objektivnih (materijalnih) razloga uglavnom ograničeni na terenska istraživanja fonologije, građu skupljaju amateri koji, iako bez formalne lingvističke naobrazbe, imaju solidan temeljni osjećaj za takvu aktivnost. ${ }^{2}$ Idealna je situacija kada oni takvu skupljenu građu prepuste na obradu znanstvenicima. ${ }^{3}$ Objektivno gledajući, to je i najidealniji način nastanka znanstvenog rječnika jer znanstvenik (osim kad je riječ o njegovu mjesnu govoru) teško da bi uspio na svojim kratkotrajnim istraživanjima (najčešće na temelju upitnika) skupiti leksik dostatan za rječnik ozbiljnijeg obima. Znanstvenik će pomoću upitnika moći solidno istražiti fonologiju i morfologiju nekoga govora, ali mali su izgledi da će prikupiti obimniji leksički korpus (posebice onaj arhaičniji), pa čak i u najbolje vođenim ciljanim razgovorima jer se »najkvalitetnija« leksička građa može skupiti »iz glave« nadarenog i barem u nekoj mjeri lingvistički osviještenog izvornoga govornika, a također i njegovim sudjelovanjem u potpuno spontanoj komunikaciji izvornih govornika koji ga ne doživljavaju kao skupljača leksika. ${ }^{4}$ No tako je prikupljen leksik tek početna osnova znanstvenikova rada na kvalitetnom dijalektalnom znanstvenom rječniku koja treba biti podvrgnuta različitim postupcima koji će biti opisani u ovom radu. Ti će postupci biti opisani na temelju autorova rada na Rječniku Svetog Đurđa (Rječniku ludbreške Podravine) $)^{5}$ koji je nastao na temelju građe koju je skupio Stjepan Belović, ${ }^{6}$ umirovljeni učitelj iz Svetog Đurđa.

1 Šojat 1985: 342-343.

${ }^{2}$ Izuzetak su vlastiti mjesni govori / dijalekti uglednih dijalektologa koji građu bilježe desetljećima i čiji znanstveni rječnik objave u ozbiljnijim godinama, npr. Šimunović 2009.

${ }^{3}$ Dobar su primjer za takvu suradnju osim ovog rječnika i Rječnik Gole i Rječnik pomurskih Hrvata.

${ }^{4}$ Posebice se to odnosi na stilski obojen leksik (pejorativnost, šaljivost, vulgarnost, eufemističnost, komunikacija s djecom ...) za koji ima vrlo malo izgleda da će se u većoj mjeri pronaći u tradicionalnim načinima prikupljanja leksika.

${ }^{5}$ Belović, Stjepan; Blažeka, Đuro: Rječnik Svetog Đurđa (Rječnik ludbreške Podravine), Učiteljski fakultet Sveučilišta u Zagrebu, Zagreb 2009.

${ }^{6}$ Gospodin Stjepan Belović mi je pred 3 godine predao popis od desetak tisuća riječi (po principu riječ - značenje) i zamolio me da ga pogledam i pomognem u objavi. Prvotna intencija gospodina Belovića bila je, kao i kod većine poštovatelja zavičajnih idioma koji nisu jezikoslovci, da se rječnik objavi po jednostavnom načelu natuknica-značenje. Kako imam poveće iskustvo u skupljanju leksičke građe kajkavskih govora, posebice međimurskog dijalekta u kojem sam skupio oko 50000 riječi, prije nego što sam uzeo u ruke popis riječi pomislio sam kako u njemu neću vidjeti bogzna koliko meni nepoznatog leksika, posebice zato jer se radi o govoru koji je po svojim fonološkim i morfološkim osobinama, a u relativnom smislu i geografski (12 kilometara), vrlo blizak preloškoj skupini govora - skupini međimurskog dijalekta u kojoj sam skupio oko 20000 riječi. 


\section{Reduciranje leksikografski nepodobnih oblika iz sirove građe}

Iz sirove građe izbacio sam one oblike koji spadaju pod neku temeljnu natuknicu, a skupljač ih je stavio kao samostalne zbog leksikografskog i lingvističkog neznanja, npr. neki konjugacijski i deklinacijski oblici koji nisu eitetski, komparativi...). Nakon toga sam izostavio oblike koji bi nepotrebno opterećivali rječnik, a nemaju nikakvih fonoloških, morfoloških i semantičkih zanimljivosti, npr. većinu odnosnih i posvojnih pridjeva, deminutiva / hipokoristika, većinu imenica nastalih mocijskom tvorbom (načelno je moguće od svakoga nomen agentis muškoga roda izvesti i ženski lik) i većinu glagolskih imenica. ${ }^{7} \mathrm{Te}$ sam kategorije obradio kao posebne natuknice samo onda ako imaju neku semantičku ili tvorbenu zanimljivost ili pak je zabilježena zanimljiva rečenična potvrda, npr.:

RADUVANJE [rad'uvaĩe rad'uvaĩa] $\boldsymbol{n}$ GL. IM. < rad'uvatị se. $\square$ U̧bec̆́'aĩe l'udųm rad'uvaĩe!

MOTANJE [m'otaĩe m'otaĩa] $\boldsymbol{n}$ 1. motanje. 'Ovų m'otaĩe v'one mị je v'ẹč d'osadnų. 2. nespretno postupanje; površan rad. 'Ide mị na ž'ifce t'ọ tv'oje m'otaĩe dųk n'ẹkaj d dệlaš.

NOSEK [n'osek n'oseka] $\boldsymbol{m}$ 1. DEM. I HIP. < n'ọs. J'ọnịcị se b'aš šika k'aj 'ima m'alų f'rntastųga n'oseka. 2. ispupčenje na kanti ili vrču kroz koje se pije. $\mathrm{P}^{\prime} \mathrm{ij}$ čez n'osek na k'ôntịcị k'aj se n'aš pųl'iẹval pų 'opravịi.

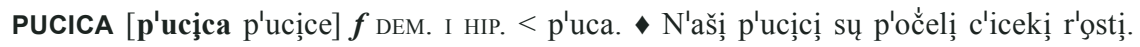
USP. p'ucka ${ }^{8}$

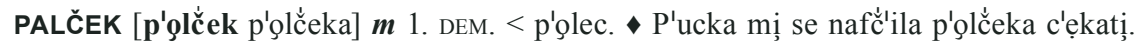
2. palčić - vrsta ptice (LAT. Troglodytes troglodytes L.).

PIJANKA [pijj'ọnka pijj'onke] $\boldsymbol{f}$ alkoholičarka. * N'ejg'orše je akų pijj'onec 'ima pijj'onkų za ž'ȩų. ${ }^{9}$

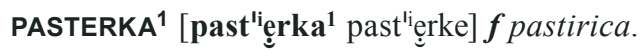

No vrlo sam brzo shvatio da nisam u pravu jer sam na svakoj stranici ugledao barem nekoliko riječi koje su mi bile potpuno nepoznate (posebice iz područja poljoprivrednog života), a broj riječi koje se odlikuju ili različitom tvorbom ili nekom posebnom fonološkom osobitošću ili posebnom značenjskom nijansom u odnosu na srodne riječi u bliskim međimurskim govorima bio je doista iznenađujuće velik. Nakon nekoliko razgovora s gospodinom Belovićem uvidio sam da to nije samo jedan od brojnih zaljubljenika u svoj mjesni govor kojeg u nekom poznijem trenutku života obuzme nostalgija za mladošću i prošlim vremenima pa iz sjećanja sastave veći ili manji popis riječi. On je te riječi skupljao dvadesetak godina, a čak se u osnovnoj mjeri uputio i u rad računala pa građa nije bila u obliku rukom ispisanih stranica.

${ }^{7}$ Po tome se koncepcija ovog rječnika razlikuje od one iz Rječnika Gole jer da se radilo po njoj, ovaj bi rječnik bio barem 3 puta deblji, no njegova obavijesnost ne bi bila mnogo veća. USP. Večenaj - Lončarić 1997.

${ }^{8} \mathrm{Uz} p^{\prime} u c k a$, drugi deminutiv / hipokorostik od $p^{\prime} u c a$, nisu zabilježeni izrazi sa spolnošću kao konotacijom.

${ }^{9}$ Zanimljiv primjer »lažnog prijatelja« (pseudoanalogonimije) prema imenici pijấnka »zabava na kojoj je došlo do pijančevanja« iz standardnog jezika. 


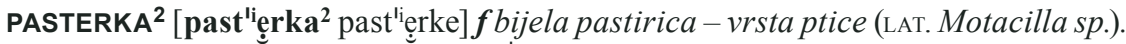

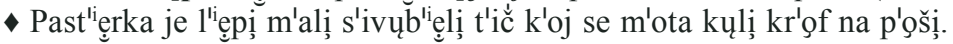

REPNI ${ }^{1}$ [r'epnị r'epnųga] $\boldsymbol{a d j}$. KOJI SE ODNOSI NA > r'ep. • Dųk se kr'avam ųp'ęrejų r'epne m'ȩtlịce, 'unda sų l'iẹpe šešųrn'ọte.

REPNI $^{2}$ [r'ẹpnị r'epnųga] adj. KOJI SE ODNOSI NA > r'ẹpa. • L'onịi smų m'ẹlị t'ak č̀'udaj r'ẹpnųga s'ẹmena da smų ga m'oglị pųs'ọdịtị 'akų je k'omų zm'ẹjnkalų.

sVATSKI [sv'ọtskị sv'ôtskųga] adj. KOJI SE ODNOSI NA > sv'atị. \ N'ẹgda sų s'amų z'imskị m’ẹsecị b'ilị sv'ôtskị z'ọtų k'aj se 'unda hr'ọna d'ože n'a kv'ọịila.

VAROŠKI [v'orųškị v'orųškųga] adj. KOJI SE ODNOSI NA > v'orųš. • V Ḷ'ubregų sų ųd tųpl'ič̉ke c'ẹste dų B'ẹdĩe z'ęmḷe k'oje se z'ovejų V'ọrųškị v'rtị.

Kod prefigiranih glagola, reducirao sam samo većinu glagola nastalih dvostrukom sativizacijom prefiksom $s$ - jer razlika u značenju u odnosu na one bez prefiksa $s$ - uglavnom se odnosi na intenzitet i doživljenost radnje. Npr. glagol

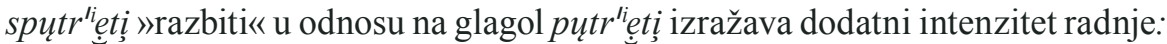
rečenica $J^{\prime} O$ te sput'esrem da te $v \breve{s}^{\prime}$ ake dųb'im! »Razbit ću te kad mi dospiješ $\mathrm{u}$ šake! « ne bi u istom značenju mogla biti zamijenjena rečenicom $* J^{\prime} O$ te put'errem da te $v \check{s}^{\prime}$ ake dų'im! Od takvih glagola ostavio sam samo one koji su u govoru izuzetno frekventni, npr. spųbr'atis »pobrati«, spred'ẹlatị »preraditi«. U tu kategoriju ne spada glagol spr'ejtị se »provesti u kretanju neko vrijeme kako bi se nakon dugotrajnog zimskog mirovanja priučilo hodu - o kravama« jer nema glagola *pr'ejti se.

U sirovoj građi bio je određeni broj leksema koji se odnose na najsuvremenije tehnološke, kulturne i sociološke realije, a također i onih leksema s kojima ispitanici imaju doticaja samo preko pisanih izvora ili elektronskih medija i koji doista nisu bili svakodnevni u ruralnom miljeu (npr. f'ormųla j'ẹdan, d'ispl'ej, t'ange, k'ontrac'epcija, ekumen'izam). Pravilna je, po mojem mišljenju, ona koncepcija izbora riječi koja će omogućiti opis tradicionalnog života hrvatskog seljaštva, otkrivanje njegovih vrijednosnih temelja i upoznavanje njegovih običaja. ${ }^{10}$

Reducirao sam i lekseme koji su u novije vrijeme prodrle iz standarda, makar se fonološki i morfološki adaptirali na govor Svetog Đurđa, npr. $v l^{\prime} a k\left(c^{\prime} u k\right)$,

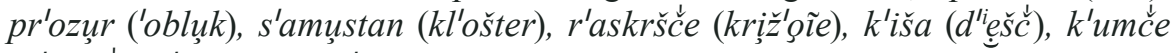

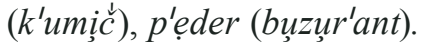

${ }^{10}$ Po tome se koncepcija Rječnika Svetog Đurđa znatno razlikuje od one u Lipljinovu Rječniku varaždinskoga kajkavskoga rječnika (Lipljin 2002). No Lipljinovu koncepciju možemo braniti jer mu je namjera bila da u rječniku odrazi duh Varaždina od kraja 19. stoljeća do danas, a na kraju krajeva, radi se o gradskom, a ne seoskom govoru pa leksemi poput kongres, $k^{\prime}$ ontraliht »protusvjetlo, svjetlo koje svijetli prema objektivu«, kompj'utȩr, korȩogr'afija i kozȩr »duhoviti pripovjedač« u njegovu rječniku imaju opravdanja, ali u rječniku seoskog govora ne bi bile prikladne, bez obzira što bi ih i neki obrazovaniji ispitanik potvrdio. 


\section{Odjeljivanje značenja i naknadno kompletiranje značenja kod polisemantičnih riječi}

2.1 U sirovoj građi bilo je vrlo rijetko obrađena polisemantičnost polisemantičnih riječi pa su obavljena vrlo opsežna naknadna terenska istraživanja zbog kompletiranja značenja. Sasvim je normalno da se prikupljač građe uglavnom fokusira na ono »zanimljivo « značenje koje neka riječ ima i kontekst u kojem ju je zabilježio, a često zaboravi na ona »uobičajena« i »obična«. Npr. kod glagola c'ureti̧ u sirovoj građi bilo je samo specifično značenje »padati - o kiši«, a nije bilo zabilježeno uobičajeno značenje »propuštati tekućinu«.

2.2 Isto je tako trebalo kod dvovidnih glagola staviti i značenje i rečeničnu potvrdu za kontekst perfektivnosti / imperfektivnosti jer je u sirovoj građi bilo naveden samo jedan kontekst, npr.

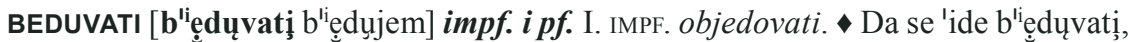

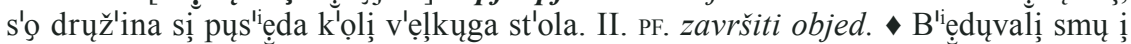
v'ę 'idemų na p'osel.

BLOMBERATI [blųmb ${ }^{\text {ie eqratị blųmb }} b^{\text {li }}$ eram impf. $\boldsymbol{i}$ pf. I. IMPF. stavljati plombu. $\mathrm{T}^{\mathrm{li}}$ e d'oktųr d'obrų blųmb"e vagọnị se moọrajų blųmb ểratị da n'ẹj št'ọ k'aj fkr'al.

2.3 Velik broj sekundarnopovratnih glagola ${ }^{11}$ iz sirove građe nije imao svoj refleksivni / prelazni parnjak. Tako je skupljač npr. zabilježio samo c'ortatĭ, ali ne i c'ortati se; $k^{\prime} u h a t i$, ali ne i $k^{\prime} u h a t i$ se; $k^{\prime} u s ̌ n u t i$, ali ne i $k^{\prime} u s ̌ n u t i s$ se. Zbog toga sam dosta vremena potrošio na terenska istraživanja gdje sam potvrdio postojanje velikog broja takvih očekivanih parnjaka, ali i našao velik broj neočekivanih parnjaka i neočekivanih značenja, npr.

BRUSITI (SE) [br'usịitị (se) br'ușim (se)] impf. I. TRANS. oštriti. \̌̌l'ajfar je zač̉'as pųst'avịil sv'ojų radijjọnịcų ị z n'ogųm v'rtel kųt'oc̆a s k'ojem je br'usịil. II. REFL. dodirivati se $u$ kretanju. N'ẹj se br'usịtị v z'it. Bųš v'ẹs b ${ }^{\text {lieẹịi. }}{ }^{12}$

DELATI (SE) [d'ẹlatị (se) d diẹlam (se), imp. d'ẹlaj (se), prid. rad. d'ẹlal (se), d'e liala (se), d'ẹlalų (se), prid. trp. d'eẹlanị, sup. d'ẹlat (se)] impf. I. TRANs. raditi. $\diamond \mathrm{M}^{\prime}{ }^{\prime}$ rate d'ẹlatị aku

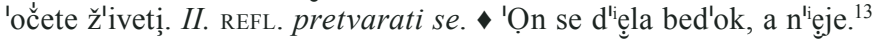

DRŽATI (SE) [drž'atị (se) drž'im (se), imp. d'ržịi (se), prid. rad. d'ržal (se), drž'ola (se), drž́alų (se), sup. d'ržat (se)] impf. I. prel. držati. D'ẹnes zd'enị s'ẹver drž'i. •'Oč̀e se

${ }^{11}$ Preciznu podjelu i terminologiju glede povratnih glagola prikazao je Branimir Belaj (Belaj 2001). U tom radu on povratne glagole dijeli na primarnopovratne glagole (oni kod kojih je u svim slučajevima prisutna povratna zamjenica, npr. ponašati se), sekundarnopovratne glagole (za razliku od primarnopovratnih glagola oni imaju paralelan prijelazni oblik bez zamjenice se, npr. osjećati se / osjećati) i tercijarnopovratne glagole (kod njih zamjenica se nije ničim vezana uz njihovo morfološko i leksičko značenje, već samo uz sintaktičko, npr. smijati se).

${ }^{12} \mathrm{U}$ sirovoj građi bilo je zabilježeno samo značenje pod $I$. TRANS.

${ }^{13} \mathrm{U}$ sirovoj građi bilo je zabilježeno samo značenje pod $I$. TRANS. 
g'ọstu por'iệ́čkatị, 'alị j'o t'ọ ne drž'im g'orị. II. Refl. 1. držati se. • D'ržịi se za r'učkų! 2. ponašati se. L Lẹ̣pų se d'ržị dųk t'ọ d'ọjdemų. 3. ponositi se. Drž'i se n'ẹkaj, a $\mathrm{n}^{\mathrm{li}}$ eูma nịtị za kr'uh! $!^{14}$

U sva 3 rječnička članka »neočekivana« značenja su kod refleksivnog glagola.

2.4 Nužno je razgraničiti homonimiju i polisemiju, ${ }^{15}$ što je u mnogim slučajevima vrlo teško, posebice tamo gdje je došlo do raspada polisemije. ${ }^{16}$ Mnoštvo je primjera u ovom rječniku gdje nije bilo lako odlučiti radi li se o homonimiji ili polisemiji, npr.

CEP$^{1}\left[\mathbf{c}^{\mathbf{l}_{\mathrm{i}}} \mathbf{p}^{\mathbf{1}} \mathrm{c}^{\mathrm{l}_{\mathrm{i}}}\right.$ ẹpa] $\boldsymbol{m}$ mladica oplemenjene biljne vrste koja se cijepi na drugu biljku kao podlogu. S'akų prt'uletje n'amestų hųt'ele pųsad'im v gųr'icaj p'ọr c c'ẹpị.

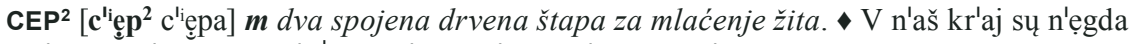
v ž'etvị z Z'agųrja dųh'ơ̆̆alị ml'ọcị s c ciẹpị ml'ọtịtị pšen'icų.

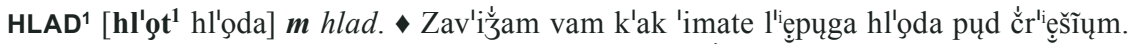

- M'ọral bųm j'ọku ưkl'ẹštritị gr'ôie na j'abųkaj. Pr'ȩveč̉ hl'ọda d'ẹlajụ.

HLAD $^{2}$ [hl'ogt ${ }^{2}$ hl'ọda] $\boldsymbol{m}$ batina. $\bullet$ V'udrịm te s hl'odụm t'ak da te m'ọm hmųr'im!

Asocijativnih veza (barem meni dokučivih) između tih parova leksema nema pa sam ih obradio kao homonime. ${ }^{17}$

Kod pridjeva $h^{\prime} u d i$ imamo primjer vrlo plodne polisemije:

HUDI [h'udị h'udųga, komp. h'ujšsị] adj. 1. loš - o hrani. \'ẹkak je h'udų m'esų ųd t'e sv'iĩe. 2. zločest. St'ajnkųvị 'imajų t'ak h'udųga p'ẹsa kaj n'išč̀e ne v'upa k î'im. N'ę zna se št'ọ je h'ujši, m'ọs ịlị ž'ȩna. 3. mršav. H'udị je. S'igųrnų je j'okų bet'ęžen. 4. ljut - o hrenu. Hr'ẹn je h'udị kaj mị s'ọze 'idejų k'ak da se pl'ọ̆em.

${ }^{14}$ Naknadnim istraživanjem zabilježeno je značenje pod II. REFL. 3.

${ }^{15}$ Tu je problematiku kod nas najbolje obradila Branka Tafra (Tafra 1995). Jedna od najvažnijih teza iz tog rada jest ta da višeznačni leksemi imaju najmanje jedan integralni sem, a u homonima su svi semovi distinktivni, ali i da još ne postoje objektivni kriteriji za semičku analizu i da je pitanje može li uopće postojati objektivna semantička analiza.

16 „Premda naši rječnici riječ park tretiraju kao višeznačnu riječ, nema razloga da već danas ne smatramo da je homonimizacija završena. Između značenja 'velik dekorativan vrt' i 'skup vozila' (automobilski park, tenkovski park) nema nikakve semantičke kohezije« (Tafra 1995: 36).

${ }^{17} \mathrm{Na}$ svojem sam izlaganju na VI. Kongresu dialektologie in geolingvistike u Mariboru spomenuo i primjere BIŠKUP ${ }^{1}$ ([b'iškųp ${ }^{1}$ b'iškųpa] $\boldsymbol{m}$ biskup. $\mathrm{B}^{\prime}$ 'iškųp je na $\mathrm{f}^{1 \mathrm{i}}$ ẹrmị s'akųga pų br'ozų m'alų k'aktị š'upill) i BIŠKUP² ([b'iškųp ${ }^{2}$ b'iškųpa] $\boldsymbol{m}$ trtica. . N'ẹkųjam je b'iškųp n'ȩjb'olši kųm'ọt ųd pec̆̀'ene č̀'uč̀e) no dr. Mijo Lončarić je u raspravi podsjetio na vezu između oblika trtice i biskupske kape. 


\section{Reduciranje nekvalitetnih rečeničnih potvrda iz sirove građe i naknadno nalaženje kvalitetnih rečeničnih potvrda u onim natuknicama gdje se one i očekuju}

Rečeničnim potvrdama u dijalektalnim rječnicima treba biti posvećena velika pozornost i upravo za taj dio rječničke natuknice uloga izvornog govornika sakupljača leksika predragocjena. Ako se rečenične potvrde pažljivo biraju, rječnik prestaje biti samo ogledalo jezičnih sustava u strukturalističkom smislu, već i prikaz manje ili više osviještenih normi, uzora, vrijednosti i očekivanja $\mathrm{u}$ antropološkom smislu. ${ }^{18}$ Autori dijalektalnih rječnika u težnji da što vjernije prikažu jezične strukture često nemaju dovoljno snage da u rječničkom članku dublje zadru u semantiku i širi sociološki kontekst upotrebe leksema. ${ }^{19}$ Najbolja je varijanta kad se uz »normalnu« rečeničnu potvrdu za neki leksem pronađe i frazem, no poželjno je da i ta »normalna« rečenična potvrda bude što zanimljivija. Najbolji je izvor kvalitetnih rečeničnih potvrda podučeni izvorni govornik koji se takvih rečenica najčešće vrlo brzo prisjeti, i to iz originalnih komunikacijskih situacija. Zbog toga je u našem rječniku velik broj rečeničnih potvrda koje završavaju na uskličnik ili upitnik, npr.

BEDAK [bed'ok bed'oka] $\boldsymbol{m}$ PEJ. budala, glupan. Bed'ọk sị b'il ị bed'ọk bųš 'ostal dųk bųš ž'if!

BELITI SE [b'elịtị se b'elịm se] impf. PEJ. duriti se pokazujući jezik. \e m’ọraš se b'elịtị! $\mathrm{N}^{\prime}$ ểsị n'ikųmų zan'imlịf!

DOGLJUMPATI SE [dųg]̣'umpatị se dųg]̦'umpam se] $\boldsymbol{p} \boldsymbol{f}$. ŠALJ. dosjetiti se. K'ak sam se

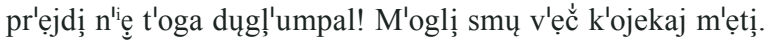

DOSPOMENUTI SE [dųspųm'enųtị se dųspųm'enem se] pf. dogovoriti se. 'Oč́eš se z m'enųm sv'adịtị ỉilị se b'omų dųspųm'enųlị k'ak se š'ika?

DOZNATI [d'oznatị d'oznam] pf. doznati. $\bullet$ K'ak vr'opcų d'ospeš s'ę t'ọ d'oznatị?

DREKAČ [dr'ekač dr'ekač̀a] $\boldsymbol{m}$ PEJ. dječak. T'i si j'an dr'ekac̆̀ k'ojemų bị j'ọ d'ọl dv'ajstị p'et na ri't!

$18 »$ Ali dijalektologija može biti pomoćna znanost i za etnologiju i sociologiju, za proučavanje kulture i civilizacije. Dijalektolog može u selu konstatirati da se ljudi danas zaista ne služe plugom. Ako je pak zaboravljena i sama riječ plug, on to mora zapisati i za genetsku lingvistiku, jer je plugf najvjerojatnije već praslavenski germanizam, a svakako je zajednička riječ germansko-slavenska. Posve je drugačija situacija ako se već radi traktorom. To je činjenica koju genetska lingvistika ignorira, ali dijalektologija kao pomoćna znanost u proučavanju etnologije, bolje rečeno etnografije, mora registrirati i tu činjenicu. Etnografija se bavi lokalnim civilizacijama« (Brozović 2004: 8).

${ }^{19}$ Kod koncepcije rečeničnih potvrda nedostižan uzor nam je bio Lipljinov rječnik. On ja za pojedine lekseme naveo čak i cijele anegdote. Npr. za leksem komunist u Lipljinovu rječniku nalazi se sljedeća rečenična potvrda: $J^{\prime} e$ dnoga $m^{\prime}$ ojęga poznậtoga su s'ędęmdeset prvẹ h'itili z p'artijẹ. S'ikak je štệl nazâj b'iti komunîst, ali ga nệsu št'eli. Dęvędessẹtẹ v jệsẹn napĩsal ję da jẹ navệk bil jugoslav'ẹnski orjẹntẹrani i t'ak je pậ postal komunîst, ali mu sẹ. Jugosl'avija pręd n'osom rẹspậla (Lipljin 2002: 311). 
U klasičnom terenskom istraživanju takvih rečeničnih potvrda ne može biti previše jer ispitanici uglavnom koriste narativnu formu u 3. licu jednine (rjeđe u 1. licu jednine), a izuzetno rijetko rečenice iz dijaloških situacija.

U prvotnoj građi normalno je da se uz one izvrsne rečenične potvrde nađe i poveći broj onih koji ne zadovoljavaju potrebitu kvalitetu, npr.:

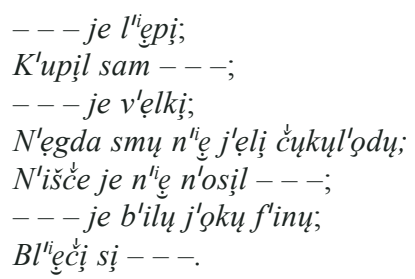

Iz ovih primjera vidljive su manjkavosti: Svašta može biti lijepo, svašta možemo kupiti, svašta nekada nismo jeli, mnogo toga ljudi prije nisu nosili ...

Za sve one natuknice kod kojih nije bilo rečenične potvrde ili je bila nekvalitetna organizirano je naknadno istraživanje. Kod nekih je natuknica zbog objektivnih okolnosti (od kojih je najznačajnija visoka dob ispitanika u kojoj im je gotovo nemoguće sjetiti se detalja koji zanimaju skupljača riječi i znanstvenika) bilo nemoguće naknadno naći kvalitetnu rečeničnu potvrdu iz živoga govora. Posebice je potrebno uložiti znatan napor da se pronađu kvalitetne rečenične potvrde kod sljedećih kategorija: a) toponimi b) etnici c) antroponimi d) fitonimi (kod njih vrlo često nedostaje rečenična potvrda, i to kod onih fitonima koji nisu imali širu uporabnu vrijednost) e) zoonimi f) nazivi jela g) odjeća i dijelovi odjeće i) uzvici (u sirovoj građi najveći dio rečeničnih potvrda iza uzvika najčešće nam nisu ništa govorili o uzviku samom)

No i u nabrojanim kategorijama kvalitetnih rečeničnih potvrda u ovom rječniku ne nedostaje. Evo nekih primjera:

STENJEVEC [Steĩ'evec Steĩ'efca] $\boldsymbol{m}$ Stenjevac-prigradski dio Zagreba. $\downarrow$ T'ȩbị se p'amet $\mathrm{m}^{\mathrm{l}} \mathrm{e}$ ša. Tr'e te ųtpeļ'atị v Steî'evec!

ĐURĐAJNČAN [Đųr亏̆'ojnč̀an Đųr亏̆'ojnč̀ana] $\boldsymbol{m}$ stanovnik Svetog Đurđa. • N'ẹgdešĩi $\mathrm{P}^{\prime}$ opųveč̀anị ị H'ẹmųfc̆̀anị v'ę se z'ovejų Đųrŏ̉ojnč̀anị.

BOLTA [B'olta B'olte] $\boldsymbol{m}$ oblik muškog imena Baltazar. K'um B'olta sų b'ilị k'arlųfskị zvųn'ọr ị dųž'ivelị sų j'okų v'ẹlkų st'arųst.

KRALJEFČıCA [kr'oḷefč̀ịca kr'oḷefč̉ịce] $\boldsymbol{f} \check{z} a b a$ gatalinka (LAT. Hyla arborea L.). Dųk

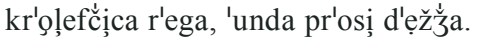

KUMIN [kųm'in kųm'ina] $\boldsymbol{m}$ kumin, vrsta začinske biljke (LAT. Anethum graveolens L.).

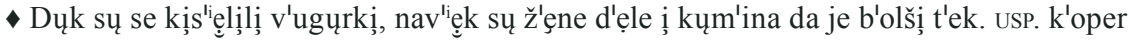

PISANIKA [p'isanịka p'isanịke] $\boldsymbol{f}$ vrsta ljetne jabuke. P'isanịke 'imajų pų s'ębị č̀rl'ene

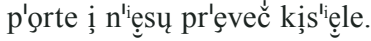

STEGANCI [st'egancỉ st'egancųf] $\boldsymbol{m}$ pl. t. vrsta kratko narezanog okruglog tijesta. F'ini $^{\prime}$ sų st'egancị dųk se pųl'iejejų s k'osanųm m'ọšč̀um v k'ojị j'ȩga n'ẹkaj cv'irkị.

CAJG [c'ajk c'ajga] $\boldsymbol{m}$ vrsta jeftine tkanine za odijelo. $\bullet$ 'ajga se nųs'ilų za s'akị

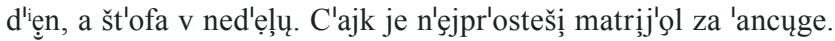


ŽUg [ž'ug] interj. uzvik za tjeranje gusaka. Ž'ug, ž'ug, ž'uga l̦'ucka! K'am vas vr'ọk k m'ȩj vų dv'ọr n'ese!

Nakon što je većina natuknica dobila kvalitetne rečenične potvrde, iz ovog se rječnika može mnogo toga iščitati o svim vidovima života stanovnika Svetog Đurđa u drugoj polovici 20. st. U mnogim su rečeničnim potvrdama u ovom rječniku očuvane narodne mudrosti, posebice prema neumjerenom gomilanju bogatstva:

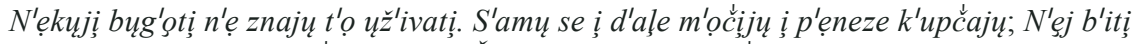

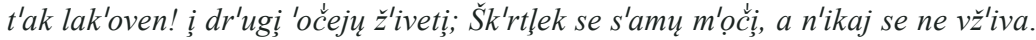

Zahvaljujući kvalitetnim rečeničnim potvrdama u ovom rječniku ostali su zabilježeni nekadašnji načini zabavljanja:

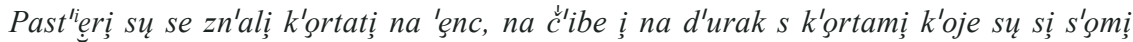
zr'ẹzali ųd kašt'ulı za c'ipele.

Današnjim aktivistima za zaštitu životinja bit će zanimljive brojne rečenične potvrde gdje se govori o postupanju prema životinjama, a posebice prema samilosti koja se danas, u doba industrijskog tretiranja životinja, često gubi:

$N^{\prime i}$ eje ļ'udskị m'orhu t'ak z b'ičùm sm'icatị kaj 'ima pu s'ębị č̀urke; Dųk se k'oḷe, gled'i se da mlad'inc̀ è c'lie evm pre fc'rkne.

I nekadašnja je oskudica realistično prikazana:

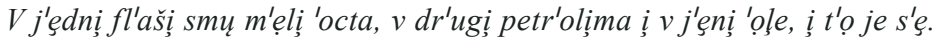

Često i s primjesama humora:

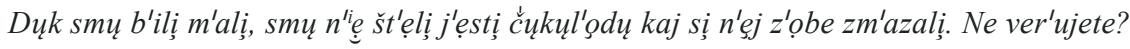

U mnogim je rečeničnim potvrdama Stjepan Belović i imenom (ponekad i prezimenom) ovjekovječio neke stvarne osobe, npr.

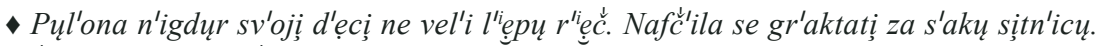

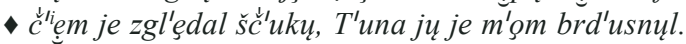

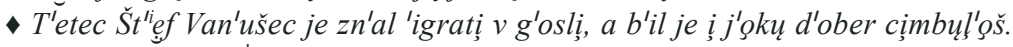

- 'Iva je b'il j'oku č c'rnuk'ožnị pak smu mu zm'išşalị c'rnec.

- Jakup, kaj je v'ure pupr'ovļal, je m’ẹl na gm'ojnị v Hrastuvsk'om sv'oju h'utu.

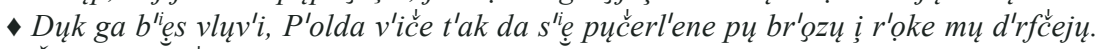

- Ślipkuf T'ajịc je b'il sļ'uga, duselen'ik netị s'om n'e znam 'otkųt.

Vrlo je složen zadatak iz rečeničnih potvrda izdvojiti frazeme. Živi narodni govor obiluje iskazima koji su na samoj granici »frazeologiziranosti«. Izdvojit ću samo neke takve iskaze:

- D'ej vam B'ọk zdrovje, a m'ajka B'ő̌a p'ẹneze ị pr'ovu p'amet!

- črez kļ'uč̀anịcu smu gl'edalị duk su se m'ẹli̧ r'adị.

- S'om je J̆'avel v t'ębị da sị t'ak hmónin!

- 'Un je t'akuf f'ahman da k'aj g'ojt mu 'oči v'idịju, t'o r'oke napr'ovijų. 
Posebice je to teško kod poredbenih frazema za koje naknadnim istraživanjima treba utvrditi jesu li u procesu idiomatizacije konvencionalizirani, djelomice desemantizirani, te se reproduciraju kao cjeline, ${ }^{20} \mathrm{npr}$.

- V gl'ovị n'iema nišst, alị 'ima j'ojca k'ak k'oũ;

- Dụk sụ me zgl'ẹdalị, t'ak sụ hm'ọnụli̧ k'ak da je j'ostrep med k'okųšị dụl'ẹtel;

- K'ak hrm'ok se punnošal;

- Kl'ipše za m’amųm k'ak c'ujzek.

- Ciggan'ička je l'iẹpa k'ak na sl'iki, s'amu da je n'e zamus'ikana;

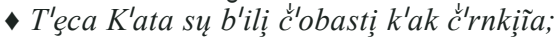

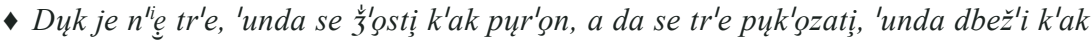
$z^{\prime}$ ojec.

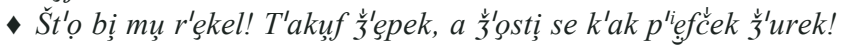

Kanonski se oblici frazema navode nakon posljednje egzemplifikacije, tj. govornog primjera koji se odnosi na natukničku riječ ili pak iza posljednje natuknice koja se odnosi na natukničku riječ u samostalnoj upotrebi. Od prethodnog su dijela leksikografskog članka odvojeni posebnim grafičkim znakom ๑. Nakon kanonskog oblika frazema u zagradi se nalazi značenje, a nakon značenja kod nekih frazema i rečenična potvrda ako je zabilježena u sirovoj građi ili je naknadno pronađena, npr.:

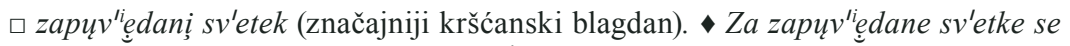

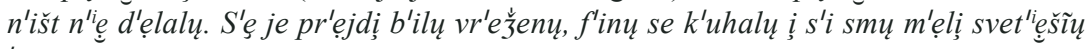
'opravu.

Jasno je da rečenične potvrde nema ako je frazem cijela rečenica, npr.:

口 Št'o 'ima str'ica, v n'ębu se dusm'ica. (Tko ima veze, uspjet će.).

\section{Određivanje arhileksema}

Na početku rječničkog članka dobro je da stoji arhileksem, i to zbog lakše čitljivosti i pristupačnosti što širem krugu čitateljstva: on je neakcentiran i pisan fonemima iz standardnog jezika, što znači da se ne bilježi otvorenost i zatvorenost samoglasnika te složenost sustava u nenaglašenoj poziciji, tj. to je pretpostavljeni oblik koji bi neki leksem imao kad bi se fonološki prilagodio fonemima iz standardnog jezika. No procijenio sam da je dobro napraviti neke izuzetke od fonološke prilagodbe natuknice na standardni jezik u arhileksemu, i to: a) nazalno $\tilde{\imath}$ u arhileksemima je prikazano kao $n j$ (KoNJ k'oĩ; SVINJA sv'iĩa); b) obezvučeni suglasnici na kraju riječi u arhileksemima su prikazani kao njihovi zvučni parnjaci (GRAD gr'ot, LABAV l'abaf).

${ }^{20} \mathrm{O}$ toj problematici vidi u Omazić 2002. 
Kada dođe do »arhileksemske homonimije«, arhileksemi se označuju brojčanim oznakama ${ }^{1},{ }^{2}$.. Jasno, »arhileksemska homonimija «e znači da postoji homonimija i među natuknicama, npr.:

BOGATI' b'ogatị uzv. i BOGATI ${ }^{2}$ bųg'ọtị adj.; DREK ${ }^{1}$ dr'ȩk dr'ȩka $m$. izmet. i DREK ${ }^{2}$

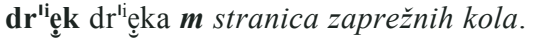

Prava homonimija bilježi se eksponentima kod kod kanonskog oblika natuknice, npr.:

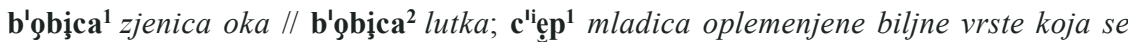
cijepi na drugu biljku kao podlogu // $\mathbf{c}^{\mathbf{l i}} \mathbf{e}$ dva spojena drvena štapa za mlaćenje žita.

\section{Određivanje definicija}

Definicije u »početnoj građi« vrlo su često netočne, manjkave i neprecizne i tu pred znanstvenikom predstoji vrlo težak zadatak napisati leksikografski prihvatljive definicije.

Kod onih leksema gdje je značenje isto kao i u standardu, a za prijevod na standard dovoljna samo fonološka i morfološka prilagodba, u definiciji sam i upotrijebio takve prijevode na standard (npr. $g r^{\prime} \rho t » \operatorname{grad} \ll, s v^{\prime} i \tilde{a} a »$ svinja «, $m r^{\prime} a s$ »mraz«, sn'ajtị se »snaći se«), a ne sinonime kao semantičke ekvivalente natuknici. Kod leksema koji se odnose na etnografsko blago (npr. običaji, igre ...) značenje sam pokušao približiti i kroz tekst koji stoji na mjestu rečenične potvrde, npr.

CINKATI SE [c'inkatị se c'inkam se] $\boldsymbol{m}$ igrati se dječje igre c'inkaĩa: Čim se zemlja osuši od snijega, dva dječaka ili više njih mogu početi s tom igrom. Svaki mora imati špekulu i nešto dugmadi koji se drže u vrećici. U zemlji se iskopa jamica (j'ac̆́ka) i tri koraka dalje od nje povuče se crta. Dječaci jedan po jedan čučnu, stave ruku na crtu i palcem zakotrljaju špekule prema jamici. Ako ničija špekula ne završi u jamici, onda onaj koji je najbliže mora s mjesta gdje je njegova špekula stala probati naciljati u jamicu. Nekada se dogodi da dvije špekule zavř̌e u jamici. Onda drugi mora prvoga st'iratị v'un, i to tako da od crte baca špekulu. Ako uspije, vlasnik mora dati dugme, a ako promaši, onda on svoju špekulu pokušava dotjerati u jamicu. Kad su sve špekule pogođene, kreće se natrag čučeći i od crte se pokušava pogoditi jamicu. Igra se tako dugo dok se dugmad iz jedne vrećice ne presele u druge. Onaj koji je sve izgubio, mora se pobrinuti da ih natrag pribavi, makar s nečije odjeće, a onda i šiba može imati posla.

KOTAČATI SE [kųt'ọc̆atị se kųt'oc̆́am se] impf. vrsta igre za dvojicu ili četvoricu igrača - Svaki igrač treba imati palicu (t'očka / kut'oc̆ka). Protivnici su udaljeni dvadeset koraka jedni od drugih, a na sredini je granica. Mali okrugli predmet (kut'oc̆) rukom se zakotrlja preko granice, a igrač ga na suprotnoj strani udara palicom kako bi ga vratio natrag. Na čijoj se strani kotač sruši (c'rkne), njima se računa pogreška. Igra traje tako dugo dok jedna strana ne napravi deset pogrešaka. Nakon toga protivnici zamijene strane i nastavljaju igru. 
Kod mnogih sam leksema upotrijebio definiciju koja najčešće nije opis njezina cjelokupna značenja, već samo polazna točka za razumijevanje i upotrebu svih njezinih potencijalnih značenja.

Kod nekih se natuknica uputnicom v. (vidi) njezina definicija upućuje na neku drugu natuknicu, najčešće nalazi se kod leksičke jedinice gdje se detaljno objašnjenje nalazi kod neke druge tvorbeno srodne leksičke jedinice, npr. objašnjenje

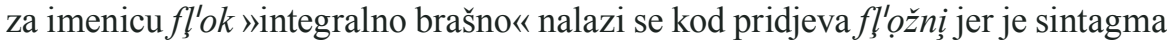
fl'ožna m'eļa frekventnija u govoru negoli imenica $f l_{\text {lo }}^{\prime}$ k i ne bi bilo ekonomično dva puta davati isto objašnjenje. Isto se tako imenica $k u t^{\prime} \rho c ̌ k a ~ » p a l i c a$ u igri kųt'oc̆aĩa upućuje na glagol kųt'očatị se gdje se detaljno opisuje cijela igra.

\section{Gramatički elementi rječničkog članka}

Ako se pravilno odaberu gramatički elementi rječničkog članka, rječnik može pružiti sve gramatičke podatke bez da bude preopsežan i nečitljiv. Nakon odrednice vrste riječi kod deklinabilnih riječi obvezno dolazi genitiv jednine (kod imenica koje su pluralia tantum genitiv množine), a kod glagola 1. lice jednine prezenta (3. lice jednine kod glagola kod kojih bi 2. ili 3. lice jednine bilo nerealno, tj. u praksi nepotvrdljivo, npr. čv'apatị $j d$. 3. čv'opa; dųzr'ẹletị jd. 3. dųzr ${ }^{1} e_{\text {eli }}{ }^{21}$ ). Nakon tih obveznih oblika ostali se oblici donose samo ako se u nekom od njih nalazi neka naglasna promjena ili promjena kvalitete samoglasnika u odnosu na genitiv jednine ili 1. lice jednine prezenta.

Također treba naglasiti da čitatelj treba podrazumijevati sljedeće morfološke dvojnosti / trojnosti ... koje postoje u govoru, a nisu zabilježene u gramatičkom dijelu rječničkog članka:

a) G mn. imenica E-deklinacije može biti s nastavkom - $-\underset{j}{\mathrm{i}}$-ø:

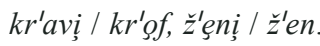

b) Većina glagola u 3. 1. mn. prezenta ima dulji lik s generaliziranim morfom -jư i kraći oblik bez njega, npr.:

lụv'ijụ / lụv'e, kr'ọdejụ / kr'ọdụ, sp'ijụ / sp'e, laž'ejụ / laž'ọ, vel'ijụ / vel'e.

Izuzetak su glagoli V. vrste.

c) Ako se kod pridjeva radnog navede samo muški rod jednine, tada u ostalim oblicima pridjeva radnog nema ni akcenatske promjene ni promjene kvalitete naglašenog samoglasnika u odnosu na muški rod jednine. Npr. kod prid. rad. bl $l^{\prime i}$ ẹkel (se) naveden je samo muški rod, a to znači da treba podrazumijevati sljedeće oblike u jednini i množini:

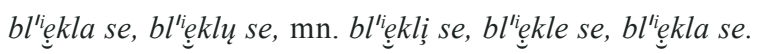

${ }^{21}$ Kod sekundarnopovratnih glagola gdje je 1. 1. jednine nerealno kod refleksivnog oblika, ono se ipak donosi ako je realno 1. 1. prelaznog oblika, npr. ųced'itị (se) ųced'im (se); ųdškr'inųtị (se) ųdškr'inem (se). 
d) Ako se kod pridjeva radnog navedu sva 3 roda jednine, a ne spominju se množinski oblici, tada je u množinskim oblicima naglasak i kvaliteta naglašenog samoglasnika kao u srednjem rodu jednine. Npr. kod slijeda prid. rad. $b^{l i} e \check{z} a l$, bežola $b^{l i} e e_{z}$ alu treba podrazumijevati sljedeće oblike u množini:

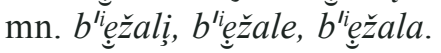

e) U pridjevsko-zamjeničkoj deklinaciji u GDL jednine mogući su dulji i kraći oblici. U rječničkom članku navode se samo dulji oblici jer su češći u govoru (n'oruga, l'e êpuga).

f) U DLI mn. svih imeničkih deklinacija postoji dvojnost (pa i trojnost) nastavaka zbog fakultativnog ispreplitanja tih nastavaka u svim kombinacijama. To je danas vrlo česta situacija na kajkavskim područjima pa je nije potrebno posebno obrađivati jer bi njezina obavijesnost bila mala, a opseg rječnika znatno bi se povećao. Npr. kod imenice $r^{\prime}$ oka treba podrazumijevati sljedeće oblike za DLI množine:

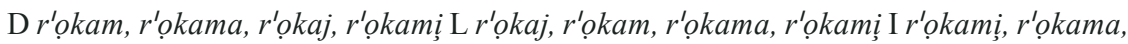
rọkaj, rọkam.

Kod imenice $b e d^{\prime} g k$ treba podrazumijevati sljedeće oblike za DLI množine:

D bed'okųm, bed'okịma, bed'okaj L bed'okịma, bed'okaj, bed'okị I bed'okị, bed'okịma, bed'okaj.

Kod imenice $r^{\prime}$ ȩbru treba podrazumijevati sljedeće oblike za DLI množine:

D r'ebram, r'ebrị, r'ebraj L r'ebraj, r'ebram, r'ebrị I r'ebrị, r'ebraj, r'ebram.

Oblike u svakom pojedinom padežu poredao sam prema uobičajenosti nastavaka koja se nadaje iz povijesti jezika, ali i učestalosti u živom govoru. Vidljivo je da se te dvije uobičajenosti poklapaju.

\section{Obrada natuknica koje imaju isto značenje (raznokorijenskih} istoznačnica, leksemskih fonoloških dubletama, leksemskih tvorbenih dubletama, imenica koje se pojavljuju u 2 roda)

Sve natuknice koje imaju isto značenje povezane su uputnicama $=i$ usp. Uputnica usp. stoji kod »glavne« istoznačnice, a kod »podređenih« istoznačnica uputnicom = upućuje se na »glavnu« natuknicu. Značenja i rečenične potvrde dolaze samo kod »glavne« istoznačnice. Kod »podređenih« istoznačnica dolazi samo odrednica vrste riječi i gramatička obrada. Izuzetno se i kod »podređene« istoznačnice navodi rečenična potvrda ako je osobito zanimljiva, ali bez značenja koje treba pogledati kod »glavne« istoznačnice na koju se upućuje.

Istoznačnica je zabilježeno mnogo, a mogu se podijeliti na sljedeće vrste. ${ }^{22}$

${ }^{22}$ Najprije navodim manje frekventnu istoznačnicu. 
a) raznokorijenske istoznačnice, npr.:

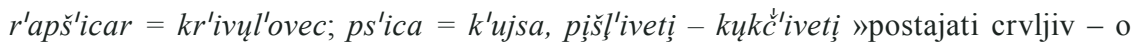
voću«, nadųvệnku = nap'uhĩenec

b) leksemske fonološke dublete, npr.:

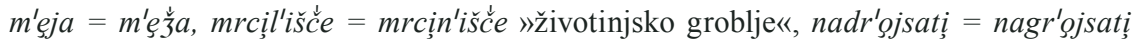
»nagrabusiti «, naj'ampųt = naj'ęmput $»$ najednom «, sųh'olek = sųh'orek »suharak«,

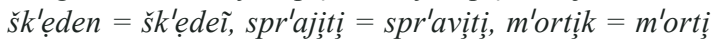

c) istoznačnice koje su rezultat tvorbene sinonimije, npr.:

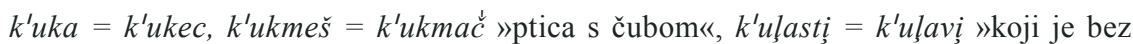

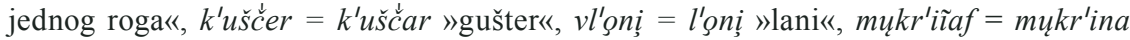
»vlaga«, biçc'alu / b'ička »držak biča«, br'uļa - br'uļeš »nesposobnjaković«, b'ujda = $b^{\prime}$ ujdeš »osoba slabe inteligencije«, $c^{\prime}$ artlek = $c^{\prime}$ arteš »razmaženo dijete«, $\mathrm{cm}^{\prime} i z d r e k-$

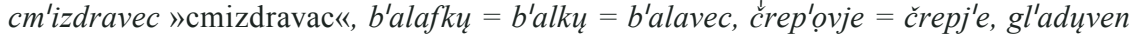
$=$ gl'aden; $g r^{\prime}$ obec $=$ gr'obek

d) imenice koje su pojavljuju u 2 roda, npr.:

'atres $=$ atr'esa, c'ipeļa $-c^{\prime}$ ipel,,$j^{\prime}$ oku $={ }^{\prime}$ oka ${ }^{23}$

Neke leksemske fonološke dublete čija se zornost može izraziti fonemom u zagradi zbog ekonomičnosti i bolje preglednosti rječnika obrađuju se u istoj natuknici, npr. prilozi s naveskom i bez njega - npr. nask'oru( $(m)$, m'ortị( $(k)$, nad'ogum (a), b'orme( $(\check{s})$; fonološke dublete u kojima u jednom parnjaku jedan suglasnik zvučni, a u drugom parnjaku bezvučni, npr. puštamb $(p) l^{l i}$ eratị $^{24}$; fonološke dublete u kojima se u jednom parnjaku pojavljuje $j$ u medijalnoj poziciji između samoglasnika i suglasnika, a u drugom ne, npr. $p r^{\prime} e(j) d i$; fonološke dublete u kojima jednom parnjaku otpadaju završni fonemi, a drugom ne, npr. 'ajd(e), $\stackrel{c}{ }^{\prime} i j i$ / $\stackrel{c}{c}^{\prime} i$; fonološke dublete u kojima je u jednom parnjaku došlo do pojednostavljenja suglasničke skupine, a u drugom nije, npr. $\stackrel{c}{c}(r) e z$.

Povelik broj istoznačnica koje su rezultat tvorbene sinonimije, osim uobičajenih razloga kao što su nestandardiziranost mjesnog govora, ispreplitanje starijeg i novijeg stanja i sl., može se tumačiti i činjenicom da Sveti Đurđ dugo nije bio koherentna cjelina, već se sastojao od 3 cjeline od kojih je svaka imala svoje varijante leksika. Koje su istoznačnice dio jednog sustava, a koje pojedine cjeline Svetog Đurđa, danas je nemoguće točno utvrditi.

Važan je zadatak bio i određivanje leksikografske »nadređenosti« jedne istoznačnice drugoj (drugima), tj. kod koje će se natuknice donijeti cjelovita obrada, a kod koje će osim gramatičke obrade biti uputnica na onu »nadređenu«. Glavni je kriterij po kojima je neka istoznačnica leksikografski postala »nadređena« drugoj veća frekventnost i veća uobičajenost u živom govoru, a ako se takvo

${ }^{23}$ Zanimljiv rod imaju i imenice j'ata »jato« i $r^{\prime}$ ẹ $u m$ »muški rod «.

${ }^{24}$ Ako se takvi suglasnici nalaze na početku riječi (npr. bec'iklịn / pec'ikli̧n, d'rmastị / t'rmastis), tada se u rječniku nalaze dvije posebne natuknice. 
nešto ne može utvrditi ni za jednu istoznačnicu, onda »nadređena« postane ona koja ima kvalitetniju rečeničnu potvrdu ili naprosto dolazi prije po abecedi.

Trebalo je i provjeriti da li kojim slučajem neka od istoznačnica pripada nekom drugom susjednom mjesnom govoru. Ipak sam u korpusu izuzetno ostavio nekoliko leksema koji ne pripadaju govoru Svetog Đurđa već susjednim mjestima ako se radi o nekim važnim toponimima kao što je npr. rijeka Bednja:

BEDNJA [B'ẹdĩa B'ẹdĩe] $\boldsymbol{f}$ rijeka Bednja. $\bullet$ B'ẹdĩa zv'ira pre Tr'akųšč̀anų, a v Dr'ovų se, n'akųn st'ọ tr'i kịlųm'ẹtrị vl liẹva pre M'alem B'ukųfcų. (Sveti Đurđ) UsP. B'ẹia

BENJA [B'ẹĩa B'ẹĩe] $\boldsymbol{f}$ (Ludbreg, Hrastovsko, Kučan, Sigetec, Slokovec) v. B'ẹdĩa

\section{Obrada natuknica koje imaju blisko značenje}

Kvaliteti rječnika također će mnogo doprinijeti i međusobno upućivanje natuknica koje imaju blisko značenje. Takvih je sinonimskih nizova mnogo i bitno je naknadnim terenskim istraživanjima pouzdano utvrditi je li riječ o bliskoznačnicama između kojih postoji samo razlika u stilskoj upotrebi ili o bliskoznačnicama između kojih postoje i razlike u nijansama značenja. Ako je razlika u stilskoj upotrebi, najčešće je za potpunu definiciju dovoljno staviti iza odrednice vrste riječi odgovarajuću kraticu koja određuje vrstu stilogema: PEJ., DJEČ., vULG., ŠALJ., ŽARG. i uputiti na neutralnu natuknicu. Jasno, kod neutralnih natuknica kraticom npr. usP. uputit će se na stilski obojenu bliskoznačnicu, i to na sve ako ih ima više, ali i na ostale bliskoznačnice koje opisuju sličan pojam.

Evo nekih primjera za bliskoznačnice između kojih postoji razlika u stilističkoj obojenosti:

SPATI [sp'atị sp'im, imp. sp'i, prid. rad. sp'ol, sp'ola, sp'alų, sup. sp'ot] impf. spavati. Dųk se f'ẹjst nad'ẹlam m'orem t'rdų sp'atị brez s'ake br'ige. usP. c'rkatị, h'ajatị, h'ajkịtị

CRKATI [c'rkatị c'rkam] impf. PEJ. spavati. Pų n'oč̀i b'ančițiti, a pų dn'evų c'rkatị, t'ak t'ọ d'aļe n'a 'išlų! v. sp'atị

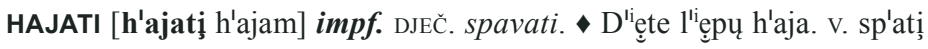

HAJKITI [h'ajkịtị h'ajkịm] impf. DJEČ. spavati. • 'Idemų h'ajkịtị da tị pr'ič̣ịcų sprepų-

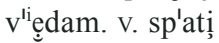

BOGATAŠ [bųgat'oš bųgat'oša] $\boldsymbol{m}$ bogataš. Bųgat'oš b'aš ne m'islị na t'ọ k'ak sịr'otịĩa Ž'ivị. usP. buggat'un

BOGATUN [bųgat'un bųgat'una] $\boldsymbol{m}$ PEJ. bogataš. $\downarrow$ Bųgat'un sị m'ore k'ojek'aj prev'ọščititi k'aj și več́'ina b'ọkcị n'ẹbrejų. v. bųgat'ọš

NOGA [n'oga n'oge] $\boldsymbol{f}$ noga. N'ogų sị je ft'rgel na 'utakmịcị. usP. c'ikųta

CIKOTA [c'ikųta c'ikųte] $\boldsymbol{f}$ PEJ. noga. M'ẹknị d'olị t'e smrdḷ'ive c'ikųte s kl'ọpe! v. n'oga

CIPEL [c'ipel c'ipela] $\boldsymbol{m}$ cipela. $\diamond J^{\prime}$ ẹn c'ipel mị se zdr'opal, B'ọm ga dn'esel Š'ipkųvųmų k'umų Fr'ancų da mị ga zak'rpajų. USP. c'ipę̧a $i$ c'ọkel

COKEL [c'ọkel c'ọkla] $\boldsymbol{m}$ PEJ. cipela. Da sų k'um M'arkų 'išlị k m'ẹṣ̌i, t'ak sų n'oge vl'ẹklị kaj sų s c'ọklị c'ẹstų d'rlị. v. c'ipelj 


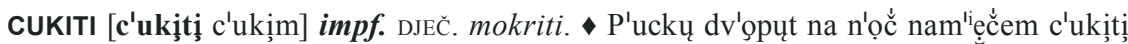
na k'ọhlịcų da mị p'ostel̦ų ne zašč́'i. v. sc'atị

LULATI [I'ulatị l'ulam] impf. EUF. mokriti. v. sc'atị

SCATI [sc'ati ššc'im, imp. šč́i, prid. rad. sc'ol, sc'ola, sc'alų, sup. sc'ot] impf. vULG. mokriti.

- N'ȩ sme se sc'atị d'ẹ se št'ọ zm'islị. usP. c'ukịtị $i$ l'ulatị

RA(E)SF(P)RČKATI [ra(e)sf(p)'rĕ́katị ra(e)sf(p)'rč̀kam] pf. PEJ. protratiti. • L'ẹfkų je rasf'rč̉katị, alị je t'ęšku presk'rbetị. USP. sf(p)'rč̀katị $i$ sp'ič́katị

SF(P)RČKATI [sf(p)'rč̀ katị sf(p)'rč̀kam] pf. N'ẹkųjị sų t'ak n'ẹrazųmnị kaj s'ẹ sf'rč́kajų.

- Vel'i da je fl'ętnų napr'avịl, a s'ȩ je s'amų sp'rč́kal. = ra(e)sf(p)'rč́katị $i$ sp'ič́katị

SPIČKATI [sp'ič̀katị sp'ič́kam] pf. 1. vULg. upropastiti imovinu. • Pr'odal je z'ȩmļu ị za c̆̀'as je 'uspel sp'ič́katị s'ẹ p'ẹneze. v. ra(e)s(f)p'rč̀katị $i \mathrm{sf}(\mathrm{p})$ 'rč̀katị 2. vULG. odbaciti nekoga. Dųk me tr'ẹbal, sam mų d'ober b'il, a v'ẹ me sp'ič̉kal da mų v'ẹc ne tr'ẹbam.

ZMISLITI (SE) [zm'islịtị (se) zm'islịm (se)] pf. I. TRANs. izmisliti. \r'ọbajte n'ẹkaj zm'islịtị k'aj bị nam b'ilų b'ol̦e napr'avịtị: z n'ọva d'ẹlatị k'oce ịlị s'amų st'ọre pųpr'avịtị. II. REFL. sjetiti se. $N^{\prime} i k a k$ se n'ẹbrem zm'islitị k'omų sam pųs'ọdịl gl ẹtvų, a n ${ }^{1 /}$ eje mị v'rnųl! USP. dųgḷ'umpatị se

DOGLJUMPATI SE [dųg]̣'umpatị se dųg]̦'umpam se] $p \boldsymbol{f}$. šalu. dosjetiti se. $\bullet$ K'ak sam se pr'ẹjdị n' nẹ t'oga dųg|̣!'umpal! M'oglị smų v'ẹc k'ojekaj m'ẹtị. v. zm'islịtị (se)

PENEZ [p'ẹnes p'ẹneza, $p l$. G pen'es] $\boldsymbol{m}$ novac. Sḷ'uži p'unų pen'es v Z'ogrebų. $\square$ Brez pen'es sam k'ak B'ọk bez br'ata. UsP. k'inta

KINTA [k'inta k'inte] $\boldsymbol{f}$ ŽARG. novac. Netị k'inte v'ẹč ųd m'ȩne ne dųb'iš, m'akar se na gl'ovų pųst'ovišs! v. p'ẹnes

Tu će ući i primjeri gdje je kod druge bliskoznačnice već stupanj pejorativnosti ili vulgarnosti već samog po sebi negativnog značenja nego što je to kod osnovne natuknice, npr.

PIZDA [p'izda p'izde] $\boldsymbol{f}$ 1. vUlg. ženski spolni organ. $\mathrm{N}^{\prime}$ ẹda se $\mathrm{n}^{\mathrm{li}} e \underline{\text { e sm }} \mathrm{sm}^{\mathrm{li}}$ ella p'izda v'idetị na telev'izijij. usP. p'ička, c'uca, š'olja, ž'aba (2), 2. vULG. osoba lošeg karaktera. - 'Ispal je p'izda.

CUCA [c'uca c'uce] $\boldsymbol{f}$ EUf. žensko spolovilo. Z'ọtų t'uḷkų l'indra kaj jų c'uca srb'i. $T^{\prime} \varrho Q$ c'uca je pųm'alị p'oč̀ela kųsmat'ẹtị. v. p'izda

PIČKA [p'ič́ka p'ič́ke] $\boldsymbol{f}$ vULG. ženski spolni organ. $\mathrm{P}^{\prime}$ 'ičkų tị pųt'ęrem! = p'izda

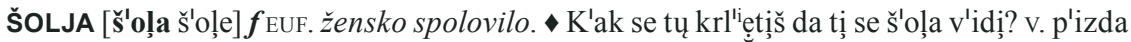

ŽABA [ž'aba žabe, $p l$. G ž'op] $\boldsymbol{f} 1$. žaba - vrsta bezrepog vodozemca (LAT. Salientia). Ž'abe v n'oč̀i v l'ẹtị r'egajų. 2. EuF. ženski spolni organ. $\mathrm{N}^{\prime}$ ejj se krl ${ }^{\mathrm{li}}$ êtịtị da tị se ž'aba ne v'idị! v. p'izda

DREK' [dr'ȩk dr'ȩka] $\boldsymbol{m}$ izmet. $\$ St'al sam v dr'ȩk. $\square$ b'itị na p'ọtų k'ak k'ọĩskị dr'ȩk (smetati) $\square$ S'am se s'rdị, dr'ȩk tị b'ọ t'rdị! (rugalica) usp. b'akač, brb'ọĩek, k'akač, l'ajnų, m'išųvịina

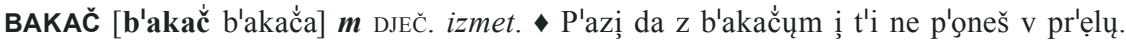
USP. dr'ȩk 
BRBANJEK [brb'oĩek brb'ỗka] $\boldsymbol{m}$ tvrdi životinjski izmet. $\downarrow$ Vr'ane sų na sn'egugų 'iskale k'ọjnske brb'ỗke. usP. dr'ȩk

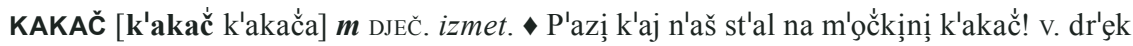

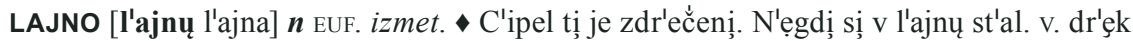
MIŠoviNA [m'išųvịna m'išųvịne] $\boldsymbol{f}$ ostaci mišjeg gnijezda i izmeta. $•$ Da se kųržĩ'ok spr'öznịl, na p'ọdų je b'ilų s'ę p'unų m'išųvịne. v. dr'ȩk

Evo jednog primjera povezanih bliskoznačnica između kojih postoji razlika u nijansama značenja, ali ih je vrlo teško konkretizirati pa su im definicije formalno iste.

BEDAČA [bed'ač̀a bed'ač́e] $\boldsymbol{f}$ glupača. $\bullet \mathrm{T}^{\prime}$ ọ bed'ač́a n'ẹ zna da ĩị se m'ọ̆ s k'umųm š'oca. USP. dr'uka $i$ h'urma

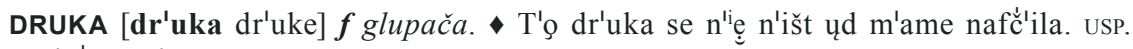
bed'ač̀a $i$ dr'uka

HURMA [h'urma h'urme] $\boldsymbol{f}$ glupača. K'akva sị t'i h'urma kaj s'ẹ v'ẹrųješ 'unam k'ojị za m'ęne k'ojek'aj l'ojajų! usp. bed'ač̀a $i$ dr'uka

Najveći je broj bliskoznačnica s nijansama u značenju zabilježen kod glagola koji izražavaju značenje »udariti«.

COPITI [c'opịtị c'ọpịm, imp. c'opị, prid. rad. c'opịl, c'ọpịla, c'opịlų, sup. c'opịt] pf. 1. pasti. Fịlịp'ina se pųsm'ẹknųla ị c'ọpịla k'ak je d'ọga. 2. EuF. udariti. \'ọ za v'ę s'amų

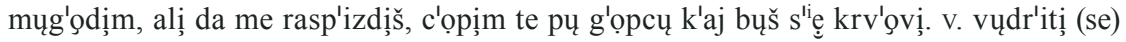

DRUKNOTI (SE) [dr'uknųtị (se) dr'uknem (se)] impf. I. PREL. lagano udariti. \ Dr'uknųl ga je z l'aktųm. II. REFL. lagano se sudariti. Z gl'ọvamị sų se dr'uknųlị t'ak da je n'ẹkaj p'oklų. v. vųdr'itị (se)

FČEHNOTI (SE) [fč́'ẹhnųtị (se) fč̀'ẹhnem (se)] pf. I. TRANS. udariti. Fč̀'ẹhnųl ga je k'aj vr'oga! II. REFL. 1. udariti se. Fờ'ẹhnųl se pų r'ọkị s h'amrųm. 2. rascijepiti se - o grani. - Sl'ive sų t'ak r'odne kaj se s'akị č̀'as m'ore k'oja sl'abeša sv'rš fč̉'ẹhnųtị. v. vųdr'itị (se)

FLAPITI [fl'opịtị fl'opịm] pf. snažno udariti prutom ili bičem. S'akị m'ore fl'opịiț sl'abešega ųd s'ȩbe, alị d'ęj t'ọ napr'avị j'akšemų! v. vųdr'itị (se)

FPORITI [fp'orịtị fp'orịm] pf. udariti bičem ili nekim tvrdim duguljastim predmetom. •

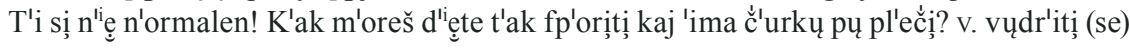

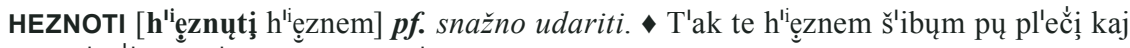
tị se b'ọ č̀'urka p'oznala! v. vųdr'itị (se)

HOZNOTI [h'oznųtị h'oznem] pf. udariti nekim predmetom. H'oznųl me s pr'otųm t'ak da 'imam č̀'urkų na pl'eč̀i. v. vųdr'itị (se)

HRKNOTI (SE) [h'rknųtị (se) h'rknem (se)] pf. I. TRANS. snažno udariti. H'rknųl ga je $\mathrm{s}$ k'ọlųm pų pl'eči t'ak da se zr'ušil k'ak da sị ga str'ẹlịl. II. REFL. ispuhnuti nos. $\mathrm{H}^{\prime}$ rknị se v r'opč̀ek. v. k'rknųtị $i$ vųdr'itị (se)

KLOPITI [kl'opịtị kl'ọpịm, imp. kl'opi, prid. rad. kl'opịil, kl'ọpịla, kl'opịlu] pf. malo udariti. - Tr'ẹba t'ȩbe kl'opịtị pų n'ọsų t'ak kaj tị p'ę k'rf! v. vųdr'itị (se) 
KRKNOTI [k'rknųtị k'rknem] pf. jako udariti. v. h'rknųtị $i$ vųdr'itị (se)

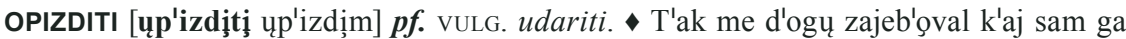
na kr'ojų m’ọral ųp'izdịtị. v. vųdr'itị (se)

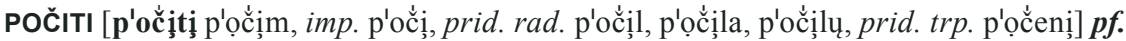
1. puknuti. 'Un je zn'al pųč́litị s p'uške dųk se n'išč̀e $\mathrm{n}^{\mathrm{li}}$ e n'odjal. 2. udariti šakom po stražnjici. • T'ak sam ga pų r'itị p'oč̀ịl kaj mị p'rstị žĩ'ovejų. v. vųdr'itị (se)

REBNOTI [r'ebnųtị r'ebnem] pf. 1. udariti. Đ'ura se s č́'ista me ${ }^{\mathrm{li}}$ ra zal'ẹtel na V'inca ị g'rdų ga je r'ebnųl. 2. PEJ. skupo zaračunati. \'ę nas je g'rdų r'ebnųl! V'ẹc n'igdųr pre İ'ẹmų n'amų n'išt k'upịilị. v. vųdr'iți (se)

SMEKNOTI [sm'ẹknųtị sm'ẹknem] pf. 1. udariti bičem ili šibom. Ž́'itkųm š'ibųm me je te bed'ôk t'ak sm'ẹknųl pų pl'eč̀i k'aj me je n'ẹkaj sp'ȩklų. 2. grubo nekome nešto reći. • Sn'ẹha je mệla d'ọguga jez'ika pųk je svek'rvị t'ak g'rdų sm'ẹknųla k'aj se ž'ȩna pl'okala. v. vųdr'itị (se)

ŠLOPITI [šl'opitị šl'ọpịm, imp. šl'ọpi, prid. rad. šl'opịl, šl'ọpila, šl'opịlu] pf. udariti po obrazu; grubo baciti. Dųk mị je Dana v'rnųla p'utra, n'ȩjrajšși bị ĩị ga b'ila šl'ọpịla! T'ak je b'il m'alị! • St'iha b'odị ịlị te šl'ọpịm pų g'ọpcų! v. vųdr'itị (se)

šUSNOTI [š'usnųtị š'usnem] pf. jako udariti.

TRESNOTI [tr'ẹsnųtị tr'ẹsnem] pf. 1. udariti. Dųk sam ga zašp'ọtal, t'iẹ b'alkų je srd'itu

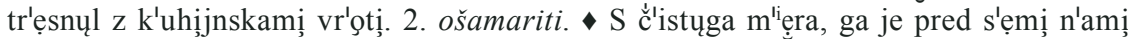
tr'ẹsnųl, t'ak k'aj mị je ga b'ilų ž'al. 3. udariti - o gromu. • Dųk grm'i, n'ejjte b'itị pųd dr'tevevum. M'oglų bị tr'ẹsnųtị. v. vųdr'iți (se)

TRESNOTI (SE) [tr'ẹsnųti (se) tr'ẹsnem (se)] pf. I. TRANS. ošamariti. Tr $^{\mathrm{li}}$ esnų̨la ga je dųk jų je št'ẹl p'ẹtatị. II. REFL. sudariti se. $\gg$ Na st'anịcị se tr'ẹsnųl t'ẹretnị vl'ọk s p'utnịčkem. v. vųdr'itị (se)

TRKNOTI (SE) [t'rknųti (se) t'rknem (se)] pf. I. TRANS. malo udariti. ga ųpųz'orị. II. REFL. sudariti se. Dųk smų se skrịv'oğ́kalị, t'ak smų se t'rknųlị da smų 'obedv'o p'alị. v. vųdr'itị (se)

VRITNOTI [vr'itnųtị vr'itnem] pf. udariti nogom. • Dųk se 'ide k'oĩų, tr'e mų se j'ovịtị, dr'ugac̆́ bị m'ogel g'rdų vr'itnųtị. v. vųdr'itị (se)

VUDRITI (SE) [vųdr'itị (se) v'udrịm (se), imp. v'udrị (se), prid. rad. v'udrịl (se), vųdr'ila (se), v'udrịlu (se), prid. trp. v'udreni] pf. I. TRANs. udariti. \'Akų ga b'aš tr'ẹba vųdrịti,

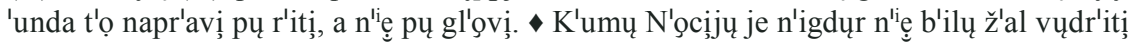
ži̧v'inč̀e. II. REFL. udariti se. V'udrịl se z h'amųrųm. usp. c'opịiț, dr'uknųtị (se), fč́'ẹhnųtị

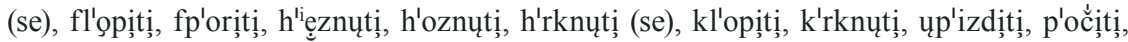
r'ebnųti, sm'ẹknųtị, šl'opiți, š' susnųtị, tr'ẹsnųtị, t'rknųtị (se), vr'itnųtị, vųdr'itị (se), zv'iznųtị

ZVIZNOTI [zv'iznųtị zv'iznem] pf. snažno udariti. T'ak te zv'iznem z 'ovem k'ọlųm da te m'om pret'rgnem! v. vųdr'itị (se)

\section{Zaključak}

Najidealniji način nastanka znanstvenog rječnika nekog mjesnog govora jest suradnja između nadarenog amatera-skupljača leksika i znanstvenika. Kako bi od sirove građe nastao kvalitetan znanstveni rječnik, ona treba biti podvrgnuta 
sljedećim postupcima u kojima u većini vrlo važnu ulogu imaju oba subjekta autorskog tandema:

Reduciranje leksikografski nepodobnih oblika b) odjeljivanje značenja i naknadno kompletiranje značenja kod polisemantičnih riječi c) reduciranje nekvalitetnih rečeničnih potvrda iz sirove građe i naknadno nalaženje kvalitetnih rečeničnih potvrda d) odjeljivanje frazema od »običnih rečeničnih potvrda e) kvalitetno definiranje značenja e) svrsishodan izbor gramatičkih elemenata rječničke natuknice f) kvalitetno povezivanje istoznačnica i bliskoznačnica.

Posebno veliku pomoć amater-skupljač leksika može pružiti kod hijerarhizacije natuknica koje imaju isto ili blisko značenje.

Nadam se da će ovaj prikaz leksikografskih postupaka pomoći onima koji su skupili ili dobili sirovu dijalektološku građu da naprave kvalitetan znanstveni rječnik mjesnoga govora.

\section{LITERATURA}

Branimir BELAJ, 2001: Prototipno-kontekstualna analiza povratnih glagola $\mathrm{u}$ hrvatskom jeziku. Zagreb: Suvremena lingvistika 51-52, 1-11.

Stjepan BELOVIĆ, 2008: Zavičajni sentimenti. Ludbreg.

Stjepan BELOVIĆ - Đuro BLAŽEKA, 2009: Rječnik Svetog Đurđa (Rječnik ludbreške Podravine). Zagreb: Učiteljski fakultet Sveučilišta u Zagrebu.

Đuro BLAŽEKA, 1998: Govor Preloga. magistarski rad u rukopisu, Zagreb: Filozofski fakultet u Zagrebu.

- -, 2000: Govor Svetoga Petra kraj Ludbrega. Zagreb: Kaj VI, 35-46.

- -, 2003: Govor Jalžabeta. Kaj 4/5 2003., Zagreb, str. 55-70.

- -, 2008: Međimurski dijalekt (Hrvatski kajkavski govori Međimurja). Čakovec, Matica hrvatska.

Dalibor BROZOVIĆ, 2004. O dijalektologiji kao jezikoslovnoj disciplini. Zagreb: Suvremena lingvistika 57-58, 1-12.

Josip HAMM, 1952: Sekundarno ije na zapadnom hrvatskom području. Zagreb: Jezik I, 39-44.

Stjepan IVŠIĆ, 1936: Jezik Hrvata kajkavaca. Zagreb: Ljetopis JAZU XLVIII, Zagreb - u ovom radu korišten je pretisak koji je 1996. objavila Matica hrvatska u Zaprešiću.

Tomislav LIPLJIN, 2002: Rječnik varaždinskoga kajkavskog govora. Varaždin.

Mijo LONČARIĆ, 1989: Istraživanje govora u ludbreškom kraju. Zagreb: Rasprave Zavoda za hrvatski jezik XV., 121-128.

- -, 2005: Kerstnerov jezik i ludbreški govor: u Kajkaviana \& alia (Ogledi o kajkavskim i drugim hrvatskim govorima). Čakovec: Zrinski, 218-231. 
Vlado NARTNIK, 1993: Obravnava naglasnih dvojnic v slovarju slovenskega knjižnega jezika. Zagreb: Rječnik i društvo - Zbornik radova sa znanstvenog skupa o leksikografiji i leksikologiji. HAZU, 271-274.

Marija OMAZIĆ, 2002: O poredbenom frazemu u engleskom i hrvatskom jeziku. Osijek: Jezikoslovlje 3. 1-2, 99-129.

Bernardina PETROVIĆ, 2005: Sinonimija i sinonimičnost u hrvatskom jeziku. Zagreb: Hrvatska sveučilišna naklada.

Mijo SABOL, 2004: Rječnik kajkavskih riječi Đelekovca i okolice: kak so govorili naši stari. Koprivnica: Vlastita naknada.

Petar ŠIMUNOVIĆ, 2009: Rječnik bračkih čakavskih govora. Zagreb: Golden marketing; Tehnička knjiga.

Antun ŠOJAT, 1985: Zasade rječnika hrvatskih kajkavskih govora. Zagreb: Hrvatski dijalektološki zbornik VII, 337-361.

Branka TAFRA, 1995: Jezikoslovna razdvojba. Zagreb: Matica hrvatska.

- -, 2005: Od riječi do rječnika. Zagreb: Školska knjiga.

Ivan VEČENAJ - Mijo LONČARIĆ, 1997: Rječnik Gole. Zagreb.

Milan ŽEGARAC-PEHARNIK, 2003: Mali tematski rječnik samoborskoga kajkavskog govora. Samobor.

\section{TEMELJNA NAČELA IN POSTOPKI PRI PRETVORBI SUROVEGA NAREČNEGA GRADIVA V ZNANSTVENI SLOVAR}

Pri nastajanju obsežnejših narečnih slovarjev je pomembno sodelovanje med jezikoslovno nadarjenim narečnim govorcem in dialektologom, saj to omogoča zbiranje arhaičnega in stilno zaznamovanega besedja ter kakovostnih stavčnih zgledov iz neposrednih (dvo)govornih dogodkov (v klasičnem terenskem raziskovanju jih ni nikoli preveč, ker informanti večinoma uporabljajo obliko za 3. osebo ednine). Na ta način zbrano gradivo mora skozi številne postopke obdelave, med katerimi avtor izpostavlja: izločanje leksikografsko neprimernih oblik iz surovega gradiva, določanje pomena oz. pomenov pri večpomenkah, izločanje nekvalitetnih stavčnih zgledov in kasnejše pridobivanje kakovostnejših pri tistih iztočnicah, kjer so ti pričakovani, določanje arhileksemov, natančno določanje definicij, izbor slovničnih kategorij v slovarskem sestavku in obdelava iztočnic $\mathrm{z}$ istim ali s podobnim pomenom. Vsi ti postopki so $\mathrm{v}$ prispevku ponazorjeni s primeri iz Rječnika govora Svetog Đurđa (Rječnika ludbreške Podravine), ki je izšel leta 2010. Neprecenljivo pomoč lahko nestrokovnjak - ljubiteljski zbiralec besedja nudi pri hierarhizaciji iztočnic, ki imajo isti ali podoben pomen (poglavitni kriterij, po katerem je določena sopomenka postala leksikografsko nadrejena, je večja pogostnost in običajnost $\mathrm{v}$ živem govoru). V tem slovarju najdemo veliko sopomenk, ki so rezultat tvorbene sinonimije, kar je posledica dejstva, da Sveti Đurd dolgo ni bil koherentna celota, temveč je bil sestavljen iz treh delov, med katerimi je imel vsak svoje leksikalne variante (danes je nemogoče ugotoviti, katere sopomenke so del enega sestava in katere del posamezne celote Svetega Đurđa). 